\title{
INVESTASI PADA REKSADANA SYARIAH DI INDONESIA
}

\author{
Dery Ariswanto \\ email: dery0712@gmail.com
}

\begin{abstract}
ABSTRAK
This article has the purpose to explain and analyze sharia investment activities in Indonesia. Investment has become one of the most popular economic activities in several developed countries, so far it has been common in developing countries, such as Indonesia. Islamic mutual fund is an interesting activity for people who will invest their wealth on the trading floor in accordance with sharia rules. As Sharia mutual funds are a means or container used to collect funds from the public which will then be invested in a portfolio of securities that is assisted by the investment manager. In this case, the securities portfolio can be in the form of money market instruments, stocks, bonds, or a combination of several forms of them. The operational mechanism in sharia mutual funds consists of two channels, first, the contract between the capital owner and the investment manager is implemented with a wakalah system. Secondly, investment managers and investment users are held in a mudharabah agreement. The basic principle in sharia mutual funds is the mudharabah or qiradh principle, which means an activity in which the capital owner gives a portion of his property to others who are competent to be further managed with the provision that the profits to be obtained from the management results are divided according to the conditions that have been agreed by both parties in advance.
\end{abstract}

Keywords: investment, Islamic mutual funds. 


\section{PENDAHULUAN}

Salah satu kegiatan ekonomi yaitu investasi, saat ini telah banyak diminati orang di negara maju juga kini sudah meluas ke negara berkembang seperti Indonesia. Investasi sejatinya adalah kegiatan menempatkan sejumlah dana dengan maksud ingin mendapatkan keuntungan dimasa yang akan datang. Aktivitas ini dapat dikategorikan kepada dua macam, yaitu riil investment dan financial investment. Investasi riil dapat dicontohkan pada investasi pembelian gedung, rumah, tanah, dll. Sedangkan investasi keuangan dapat dicontohkan pada investasi di sektor deposito, obligasi, tabungan, saham, reksadana, dan lain sebagainya. ${ }^{1}$

Investasi juga dapat diartikan sebagai sebuah bentuk penundaan pembelanjaan harta untuk kegiatan konsumsi saat ini, untuk kemudian dipergunakan untuk kepentingan kegiatan produksi yang efektif dan efisien dan dalam tengat masa yang diinginkan. ${ }^{2}$ Sehingga dengan adanya penundaan tersebut, seseorang diharapkan akan mendapatkan keuntungan yang dapat meningkatkan kualitas dan derajat kehidupannya. Hingga saat ini, stakeholder keuangan syariah di Indonesia telah gencar menyebarluaskan jenis investasi berbasis syariah, baik pemerintah maupun pihak swasta. Berbagai bentuk investasi berlabel syariah kini sudah mulai muncul seperti semakin banyaknya versi reksadana berbasis syariah yang diterbitkan,

\footnotetext{
1 Kuat Ismanto, Prospektus Reksadana Sebagai Prinsip Kejujuran Bisnis Syariah, (Jurnal Hukum Islam Volume 10, Nomor 2, Juni 2012) hlm, 277.

2 Jogiyanto, Teori Portofolio dan Analisis Investasi (Yogyakarta: BPFE Yogyakarta, 2007) hlm, 5.
}

daftar efek syariah yang diterbitkan secara berkala, adanya online trading versi syariah yang membatasi transaksi margin dan daftar saham yang ditawarkan, pemeringkatan reksadana yang terdiri dari dua versi yaitu reksadana konvensional dan reksadana syariah, dan maraknya keberadaan lembaga keuangan syariah.

Seiring pesatnya perkembangan ekonomi Islam, reksadana syariah juga telah berkembang di Indonesia. Meski istilah ini tidak sepopuler bank syariah, namun jenis investasi ini cukup berkembang dengan baik. Terdapat berbagai aspek mendasar dalam reksadana syariah yang perlu dipahami secara komprehensif, sehingga eksistensinya memiliki manfaat secara ekonomi dan juga status kehalalannya di kalangan umat Islam selaku konsumen. Oleh karena itu, menarik untuk menjadikan topik ini sebagai bahan diskusi yakni tentang bagaimana investasi melalui reksadana yang berlabel syariah di negara Indonesia.

\section{PEMBAHASAN}

\section{Reksadana Syariah di Indonesia}

Kegiatan semacam reksadana muncul pada abad 19 tepatnya tahun 1870, saat itu Robert Fleming ditugaskan ke Amerika Serikat untuk mengelola investasi milik atasannya dan di sanalah dirinya melihat peluang investasi baru. Sesampainya kembali di negara asalnya, Robert Fleming menjelaskan penemuannya tersebut kepada temannya. Dia memiliki niatan untuk memanfaatkan peluang tersebut, akan tetapi tidak memiliki modal yang cukup. Masalah tersebut mendorong 
semangatnya untuk mengumpulkan uang dari kolega dan temannya, selanjutnya pada tahun 1873 menginisiasi sebuah perusahaan manajemen investasi pertama di Inggris yang disebut The Scottish American Investment Trust atau lebih identik dikenal pada saat ini yakni reksadana tertutup (closed-end fund). ${ }^{3}$

Instrumen reksadana di Indonesia mulai dikenal sejak tahun 1995, yakni atas diterbitkannya PT. BDNI Reksadana. BDNI Reksadana berdasarkan sifatnya merupakan reksadana tertutup yang agak mirip dengan The Scottish American Investment Trust. Lahirnya Undang-undang No. 8 Tahun 1995 tentang Pasar Modal mendorong perkembangan dunia investasi dan mulailah reksadana tumbuh aktif di Indonesia.

Pendirian reksadana syariah yang berbentuk Kontrak Investasi Kolektif itu barlandaskan Undang-undang No.8 Tahun 1995 tentang Pasar Modal, yang dituangkan dalam akta Nomor 24 tanggal 12 Juni 1997 yang dibuat di hadapan Notaris Djedjem Wijaya, S.H. di Jakarta antara PT Danareksa Fund Management sebagai manajemen investasi dengan Citibank N.A. Jakarta sebagai Bank kustodian. ${ }^{4}$

PT. Danareksa pada tahun 1997 menjadi ujung tombak dalam penerbitan reksadana syariah di Indonesia. Reksadana

\footnotetext{
3 Iggi Achsien. Investasi Syariah di Pasar Modal: Menggagas Konsep dan Praktek Manajemen Portofolio Syariah. (Jakarta: Gramedia Pustaka Utama, 2000) hlm, 45.

4 Eko Priyo Pratomo dan Nugraha Ubaidillah, Reksadana: Solusi Perencanaan Investasi di Era Modern . (Jakarta: Gramedia Pustaka Utama, 2009) hlm, 65.
}

ini menjadi instrumen pasar modal pertama yang beroperasi secara syariah serta menjadi langkah awal lahirnya pasar modal syariah. Kemudian bapepam sebagai pengawas dalam hal ini mulai melakukan inisiatif untuk mewadahi investor muslim. Maka pada tahun 1997 hadirlah produk reksadana syariah yang diberi nama Danareksa Syariah. Tepat setelah tiga tahun lahirnya reksadana syariah, PT. Danareksa menghadirkan instrumen syariah yang baru, yaitu adanya Jakarta Islamic Indeks yakni sebuah badan indeks saham syariah yang memperdagangkan sahamsaham perusahaan yang terpilih dengan ketentuan prinsip operasionalnya tidak bertentangan dengan ketentuan agama Islam. ${ }^{5}$

Majunya reksadana tidak terlepas dari lahirnya Undang-Undang tentang pasar modal Nomor 8 tahun 1995, baik reksadana konvensional ataupun syariah. Dengan diluncurkanya pasar modal syariah oleh Bapepam yang bekerja sama dengan Dewan Syariah Nasional yang diawasi langsung oleh Dewan Pengawas Syariah, diharapkan agar semua pihak yang terlibat di pasar modal dapat terlindungi hak dan kewajibannya serta terhindar dari kegiatan yang dapat merugikan. ${ }^{6}$

\section{Pengertian Reksadana Syariah}

Reksadana di beberapa negara dikenal dengan istilah yang berbeda seperti di

\footnotetext{
${ }^{5}$ Abdul Manan, Hukum Ekonomi Islam, (Jakarta: Kencana, 2012) hlm, 308.

6 Hammad Dkk, Briefcase Book Edukasi Profesional Syariah Investasi Halal di Reksadana Syariah. (Jakarta: Renaisan, 2005) hlm, 4.
} 
Inggris disebut unit trust yang berarti unit kepercayaan, di Amerika dikenal mutual fund yang berarti dana bersama dan di Jepang lebih dikenal investment fund yang berarti pengelolaan dana untuk keperluan investasi berdasarkan kepercayaan. Reksadana menurut bahasa tersusun dari dua konsep kata, yaitu reksa yang berarti jaga atau pelihara dan dana yang berarti uang. Sehingga dapat dipahami bahwa reksadana adalah kumpulan uang yang dipelihara. ${ }^{7}$

Reksadana merupakan wadah yang digunakan dalam kegiatan perhimpunan dana masyarakat pemilik modal yang selanjutnya akan diinvestasikan dalam portofolio Efek oleh Manajer Investasi sebagai pengelola. ${ }^{8}$ Berdasarkan pengertian itu, maka setidaknya ada tiga poin penting dalam reksadana yakni adanya kumpulan dana dari masyarakat, manajer investasi sebagai pengelola dana yang akan menginvestasikan ke dalam bentuk portofolio efek dan dana yang dikelola oleh manajer investasi adalah dana milik investor, karena manajer investasi adalah pihak yang dipercayakan untuk mengelola dana sebagaimana reksadana merupakan sebuah wadah yang memiliki fungsi sebagai bentuk menghimpun dana dari investor untuk kemudian ditaruh ke dalam portofolio efek yang dibantu oleh manajer investasi yang telah mendapat izin dari Otoritas Jasa Keuangan. ${ }^{9}$

\footnotetext{
${ }^{7}$ Abdul Manan, Hukum Ekonomi Islam, (Jakarta: Kencana, 2012) hlm, 305.

${ }^{8}$ Pasal 1 ayat 27 Undang-Undang Nomor 5 Tahun 1995 tentang Pasar Modal

${ }^{9}$ Iggi H, Achsien. Investasi Syariah di Pasar Modal: Menggagas Konsep dan Praktek Manajemen Portofolio

Fatwa Dewan Syariah Nasional Nomor: 20/DSN-MUI/IX/2001 menyebutkan bahwa yang dimaksud dengan reksadana syariah yaitu reksadana yang dijalankan menurut prinsip syariat Islam, baik dalam akad antara pemodal sebagai pemilik harta (sahib al-mal) dengan manajer investasi sebagai wakil sahib al-mal, maupun antara manajer investasi sebagai wakil sahib al-mal dengan pengguna investasi. ${ }^{10}$ Sehingga dapat dipahami bahwa reksadana syariah adalah sarana yang dipergunakan untuk kegiatan menghimpun dana dari masyarakat yang selanjutnya akan diinvestasikan ke dalam beberapa portofolio efek yang dibantu oleh manajer investasi sebagai pengelola. Portofolio efek tersebut dapat berupa sukuk, instrumen pasar uang, saham, atau gabungan dari beberapa di antaranya.

\section{Prinsip dalam Reksadana Syariah}

Reksadana syariah adalah salah satu produk keuangan yang mengacu kepada sistem keuangan syariah dengan berpegangan pada ketentuan ajaran agama Islam yang dalam kegiatan usahanya tidak boleh ditempatkan kepada sahamsaham dan obligasi dari perusahaan yang produk-produknya bertentangan dengan syariah Islam seperti pabrik minuman atau makanan yang mengandung daging babi, alkohol, rokok, bisnis hiburan yang mengandung maksiat dan lain yang bertentangan. Reksadana syariah dalam pe-

Syariah. (Jakarta: Gramedia Pustaka Utama, 2000) hlm, 43.

10 Tim Penulis Dewan Syariah Nasional MUI, Himpunan Fatwa Dewan Syariah Nasional, Edisi kedua, (Jakata: PT. Intermasa, 2003) 
nerapannya harus mendaptkan izin dan mematuhi fatwa dari Dewan Syariah Nasional. Sebagaimana Dewan Syariah Nasional nasional telah menerbitkan Jakarta Islamic Indeks (JII) dan Daftar Efek Syariah (DES) yang dapat dijadikan sebagai tolak ukur transaksi-transaksi syariah yang keberadaan saham-saham syariah tersebut akan dievaluasi setiap 6 bulan satu kali.

Di samping itu, DSN juga memiliki tugas untuk memberikan arahan ke manajer investasi agar kegiatan investasinya di reksadana syariah tetap berada pada jalur yang tepat, menghindari gharar dan maysir. Reksadana konvensional dan reksadana syariah pada dasarnya memiliki persamaan, baik dalam bentuk sifat dan karakteristiknya. Hanya saja yang menjadi perbedaan adalah pada pengelolaan portofolio investasinya yang menerapkan prinsip syariah Islam dan prinsip operasional.

Sebagaimana dijelaskan dalam pembahasan sebelumnya bahwa reksadana syariah merupakan lembaga atau badan intermediasi yang berperan untuk membantu masyarakat surplus unit agar melakukan penempatan dana untuk diinvestasikan di lantai bursa melalui manajer investasi dengan tujuan untuk memenuhi kelompok investor yang ingin memperoleh pendapatan investasi dari sumber dan cara yang bersih dan dapat dipertanggungjawabkan secara syariah juga yang sesuai dengan prinsip syariah. ${ }^{11}$

11 M. Nur Riyanto Al Arif. Lembaga Keuangan Syariah: Suatu Kajian Teoritis Praktis. (Bandung: Pustaka Setia, 2001) hlm, 61.

\section{Perbedaan Reksadana dan Reksadana Syariah}

Jika dipahami secara spesifik ternyata terdapat perbedaan yang cukup spesifik antara reksadana konvensional dan syariah, pada reksadana syariah dikenal dengan adanya proses screening dan cleansing. Dimana proses screening merupakan sebuah proses menepatkan dana dari masyarakat di dalam portofolio yang halal. Tahap ini merupakan tahap filterisasi pertama dalam pembentukan portofolio yang memenuhi semua prinsip Islam. Kemudian tahap selanjutnya yakni cleansing yaitu membebaskan semua sarana investasi dari unsur-unsur yang diharamkan. ${ }^{12}$

\section{Bentuk dan Jenis Reksadana \\ Bentuk Reksadana}

Undang-undang Nomor 8 Tahun 1995 tentang Pasar Modal pasal 18 ayat (1) menjelaskan bahwa bentuk hukum dari reksadana di Indonesia secara umum terbagi ke dalam dua bentuk, yaitu Perseroan (Investemet companies) dan Kontrak Investasi Kolektif (Unit Investement Trust). Perseroan adalah suatu perusahaan yang bentuk hukumnya tidak jauh berbeda dengan perusahaan lainnya namun hanya berbeda dalam masalah jenis usahanya yang berupa pengelolaan portofolio efek dalam investasi. ${ }^{13}$ Sedangkan KIK merupakan sebuah kontrak yang dibuat antara

${ }^{12}$ Alvien Septian Haerisma, Pengantar Reksadana Syariah (Introduction Of Islamic Mutual Fund), AlAmwal Jurnal Kajian Ekonomi dan Perbankan Syariah, Vol 6, No. 2 (2014), hlm. 2.

${ }^{13}$ Andri Soemitra, Bank dan Lembaga Keuangan Syariah, (Jakarta: Kencana, 2009) hlm. 111. 
Manajer Investasi dan Bank Kustodian yang juga mengikat pada pemegang Unit Penyertaan sebagai Investor. Manajer Investasi melalui kontrak ini akan diberi wewenang khusus untuk mengelola portofolio efek sedangkan pihak Bank Kustodian berwewenang untuk melaksanakan administrasi investasi dan penitipan. ${ }^{14}$

\section{Jenis Reksadana}

Reksadana memiliki jenis yang berbeda meliputi: ${ }^{15}$

a. Fixed Income Fund atau Reksadana

Pendapatan Tetap

Reksadana Pendapatan Tetap merupakan salah satu upaya melakukan investasi yang paling baik dalam jangka waktu menengah atau jangka panjang dengan resiko menengah. Juga diartikan sebagai reksadana yang melakukan investasi sekurang-kurangnya $80 \%$ dari dana yang berhasil dikelola dalam bentuk efek yang bersifat utang. Kebanyakan yang memberikan penghasilan dalam bentuk bunga, seperti obligasi syariah, swbi, deposito, dan instrument lainnya.

\section{b. Equity Fund atau Reksadana Saham}

Reksadana yang melakukan investasi sekurang-kurangnya $80 \%$ dari dana yang dikelolanya dalam efek bersifat ekuitas. Kebanyakan, efek saham akan membe-

14 Fatwa DSN No. 40/DSN-MUI/X/2003 tentang Pasar Modal dan Pedoman Umum Penerapan Syariah di Bidang Pasar Modal, Himpunan Fatwa Dewan Syariah Nasional, (Jakarta: Intermasa, 2003), edisi kedua, hlm. 272.

15 Muhammad Yusuf, Bisnis Syari'ah. (Jakarta: Mitra Wacana Media, 2011), hlm. 45. rikan kontribusi dengan memberikan hasil yang menarik. Muncul banyak anggapan bahwa melakukan investasi saham lebih cenderung spekulatif atau berjudi, akan tetapi dari segi pengalaman dan teori di lapangan mengatakan bahwa investasi saham merupakan satu bagian investasi jangka panjang yang cukup menggiurkan.

\section{c. Siscretionary Fund atau Reksadana}

\section{Campuran}

Reksadana yang mempunyai perbandingan target aset alokasi pada efek saham dan pendapatan tetap yang tidak dapat dikategorikan ke dalam ketiga reksadana lainnya. Reksadana campuran ini secara orientasi lebih fleksibel dalam menjalankan investasinya, fleksibel ini diartikan sebagai pengelolaan investasi yang dapat digunakan secara random/ berpindah-pindah dari saham ke obligasi maupun ke deposit.

\section{d. Money Market Fund atau Reksadana}

\section{Pasar Uang}

Reksadana yang investasinya ditanam pada efek bersifat hutang dengan jatuh tempo yang kurang dari satu tahun. Secara umum, investasi ini meliputi SBI, Obligasi serta efek hutang lainnya. Reksadana jenis ini mempunyai tingkat resiko yang cukup kecil, namun keuntungan yang akan dihasilkan juga lumayan terbatas. Tujuannya tidak lebih hanya untuk perlindungan modal dan untuk menyediakan likuiditas yang tinggi, sehingga ketika dibutuhkan dapat dicairkan setiap hari kerja dengan resiko penurunan nilai investasi yang hamper tidak ada. 
Sementara itu jika dilihat berdasarkan sifat dari reksadana, reksadana terbagi ke dalam tiga varian, yakni: ${ }^{16}$

a. Reksadana Terbuka (open-end Fund)

Reksadana terbuka adalah perusahaan investasi yang menawarkan dan membeli kembali saham-sahamnya dari investor sampai sejumlah unit penyertaan yang sudah dikeluarkan. Reksadana terbuka memberikan peluang dalam hal keinginan untuk menjual/membeli kembali unit penyertaan. Reksadana terbuka lebih disukai investor karena lebih likuid, meskipun tidak tercatat di bursa efek. Dengan kata lain, unit penyertaannya lebih mudah diletakkan dengan harga pasar. ${ }^{17}$

b. Reksadana Tertutup (close-end Fund)

Closed-end fund adalah suatu reksadana yang cukup dikenal di Amerika Serikat yang hampir serupa dengan reksadana tertutup di Indonesia. Reksadana tertutup merupakan reksadana yang jumlah saham beredarnya tidak berubah. Dengan kata lain, reksadana tertutup hanya dapat menjual saham reksadana kepada investor sampai batas jumlah modal dasar dalam anggaran dasar.

Reksadana ini bersifat tertutup pada jumlah saham yang bisa diterbitkan atau pada saat menerima masuknya investor baru melalui penerbitan saham baru. Reksadana tertutup ini tidak membeli kembali (redeem) saham-saham yang telah dijual kepada investor, artinya investor

\footnotetext{
16 Ibid., hlm, 46.

17 M. Nur Riyanto Al Arif. Lembaga Keuangan Syariah: Suatu Kajian Teoritis Praktis. (Bandung: Pustaka Setia, 2001) hlm, 63.
}

tidak dapat menjual kembali saham-saham yang telah dibeli kepada reksadana yang bersangkutan.

Sedangkan karakteristik lain dari sifat tertutup ini meliputi, reksadana hanya dapat mengeluarkan atau menjual sahamnya sampai batas modal dasar, tidak membeli kembali saham-sahamnya yang telah dijual kepada investor, investor tidak dapat menjual kembali saham reksadana yang dimiliki dan reksadana dicatat di bursa efek (pasar sekunder). ${ }^{18}$

\section{c. Unit Investment Trusts}

Unit Investment Trust adalah suatu perusahaan di bidang investasi yang tugasnya membeli portofolio efek dengan menggunakan kumpulan kekayaan dari pemegang saham atau unit penyertaan. Portofolio obligasi kemudian akan disimpan pada Trustee sebagai kustodian langsung sampai dengan batas jatuh tempo dari obligasi tersebut.

\section{Mekanisme dan Operasional Reksadana Syariah}

Reksadana syariah dalam rumpun pembahasan keuangan syariah dapat dimaknai menggunakan istilah Islamic Investment Fund atau Syariah Mutual Fund. Reksadana syariah adalah lembaga intermediari yang membantu pihak surplus unit untuk melakukan penempatan dana yang kemudian akan diinvestasikan kembali (reinvestment) pada beberapa portofolio efek yang dibenarkan syariah. Adanya investasi jenis ini bertujuan untuk memberikan kemudahan bagi calon in-

\footnotetext{
${ }^{18}$ Muhammad Yusuf, Bisnis Syari'ah., hlm. 46.
} 
vestor dalam menjalankan investasi di pasar modal dan untuk memenuhi kebutuhan kelompok investor yang menginginkan keuntungan dari sumber dan mekanisme investasi yang bersih serta dapat dipertanggung-jawabkan. ${ }^{19}$ Adapun operasional dalam Reksadana Syariah terbentuk dari:

1. Kegiatan antara pemodal dan Manajer Investasi dilakukan dengan sistem wakalah.

Penggunaan akad wakalah dalam kontrak antara pihak investor dengan manajer investasi ini poinnya adalah perjanjian pemberian kuasa kepada menejer investasi untuk melaksanakan tata kelola dana yang telah dipercayakan, yang bertujuan untuk mendapatkan keuntungan dari dana yang diinvestasikan. Manajer investasi menggunakan akad wakalah yakni dimaksudkan untuk menjadi wakil demi kepentingan dan atas nama investor.

2. Kegiatan antara manajer investasi dengan pengguna investasi dilakukan menggunakan akad mudharabah.

Dalam hal ini manajer investasi bertindak sebagai mudharib dalam akad mudharabah, namun tidak sebagai mudharib murni karena reksadana syariah menempatkan kembali dana ke dalam kegiatan emiten melalui pembelian efek syariah. ${ }^{20}$ Adapun prinsip mudharabah di reksadana syariah ini memiliki beberapa ciri-ciri yakni:

19 Eko Priyo Pratomo dan Nugraha Ubaidillah. Reksadana: Solusi Perencanaan Investasi di Era Modern, (Jakarta: Gramedia Pustaka Utama,2009) hlm, 83.

${ }^{20}$ Andri Soemitra, Bank dan Lembaga Keuangan Syariah, (Jakarta: Kencana, 2009) hlm, 109. a. Manajer Investasi tidak menanggung resiko kerugian atas investasi yang dilakukannya sepanjang bukan karena kelalaiannya (gross negligence) tafrith).

b. Pemodal hanya menanggung resiko sebesar dana yang telah diberikan.

c. Pembagian keuntungan antara pemodal (sahib al-mal) yang diwakili oleh Manajer Investasi dan pengguna investasi berdasarkan pada proporsi yang telah disepakati kedua belah pihak.

Sedangkan mekanisme dalam reksadana memiliki dua prosedur yaitu:

\section{Kegiatan Pembelian}

Pastikan untuk membaca prospektus sebelum membeli reksadana, prospektus yaitu buku/kumpulan materi yang berisi informasi mengenai berbagai hal terkait dengan reksadana. Prospektus juga mencantumkan latar belakang reksadana, manajer investasi, potensi keuntungan, risiko investasi, dan gambaran portfolio investasi reksadana. Investor dapat langsung membeli ke perusahaan manajer investasi atau melalui agen penjual (bank) dengan mengisi form pembukaan rekening reksadana, form pembelian unit penyertaan, dan fotokopi identitas. ${ }^{21}$

\section{Kegiatan Penjualan}

Sedangkan untuk menjual, cukup dengan mengisi formulir penjualan dan menyampaikannya pada perusahaan manajer investasi atau melalui agen. Penjualan bisa dilakukan kapan saja, dan

\footnotetext{
${ }^{21}$ Muhammad Yusuf, Bisnis Syari'ah.., hlm. 47.
} 
membutuhkan proses 4-7 hari bursa ditentukan sebelumnya. Berikut ini adauntuk mencairkan dananya yang kemulah pola mekanisme yang dilakukan oleh dian akan dikirimkan melalui transfer beberapa pihak di reksadana: langsung ke rekening bank yang sudah

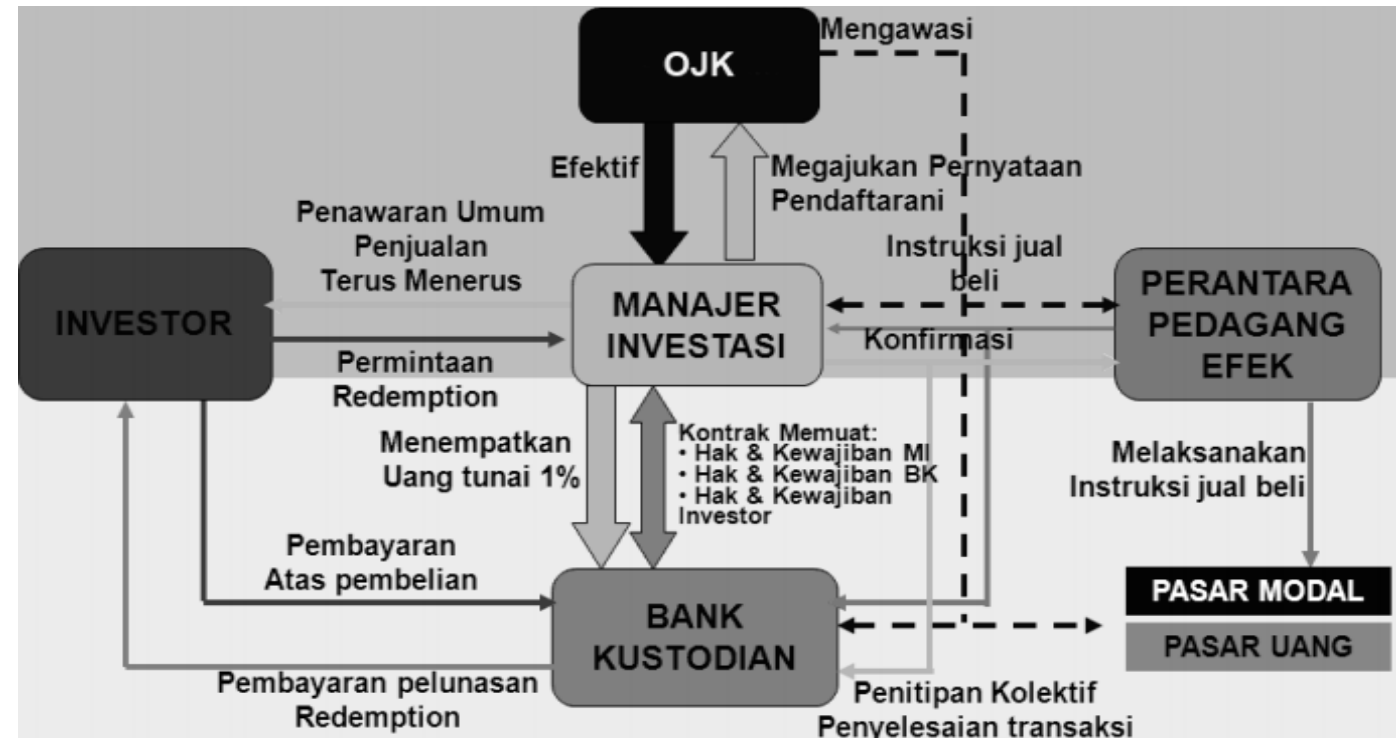

Gambar 1: mekanisme reksadana

\section{Kendala dan Strategi Pengembangan Reksadana Syariah}

Dalam upaya pengembangan reksadana syariah di Indonesia ternyata masih belum begitu optimal, hal itu dikarenakan masih terdapat kendala-kendala dalam pengembangan reksadana syariah sehingga akan berdampak kurang maksimalnya peran lembaga keuangan non-perbankan dalam upaya menghimpunan dana dari masyarakat untuk melakukan investasi di reksadana syariah. Adapun kendala itu antara lain yaitu:

1. Pengetahuan masyarakat yang minim atau belum dikenalnya produk investasi berbasis syariah dalam bentuk reksadana di beberapa daerah.

2. Minimnya instrumen pembiayaan di pasar modal sehingga sulit bagi in- vestor untuk menginvestasikan dana.

3. Dualisme sistem dalam reksadana di Indonesia. ${ }^{22}$

Berdasarkan kendala di atas, maka perlu adanya strategi khusus sebagai upaya untuk menjawab kedala pengembangan reksadana syariah di Indonesia, strategi yang dapat dikembangkan antara lain yakni:

1. Sinergi antara lembaga-lembaga yang terkait baik bapepam, praktisi, akademis, ulama, dan pengusaha dalam mambangun sistem ekonomi syariah terutama di pasar modal.

2. Memperbanyak jenis reksadana syariah gunan memberikan alternative investasi bagi masyarkat untuk me-

\footnotetext{
${ }^{22}$ Abdul Manan.., hlm. 312.
} 
nyimpan dananya di reksadana syariah.

3. Perlunya usaha sosialisi idealisme tentang reksadana syariah. nesia sejak tahun 2014 hingga memasuki awal tahun 2020 sebagai bahan pertimbangan bahwa reksadana syariah semakin hari telah akin berkembang:

Berikut ini merupakan statistik perkembangan reksadana syariah di Indo-

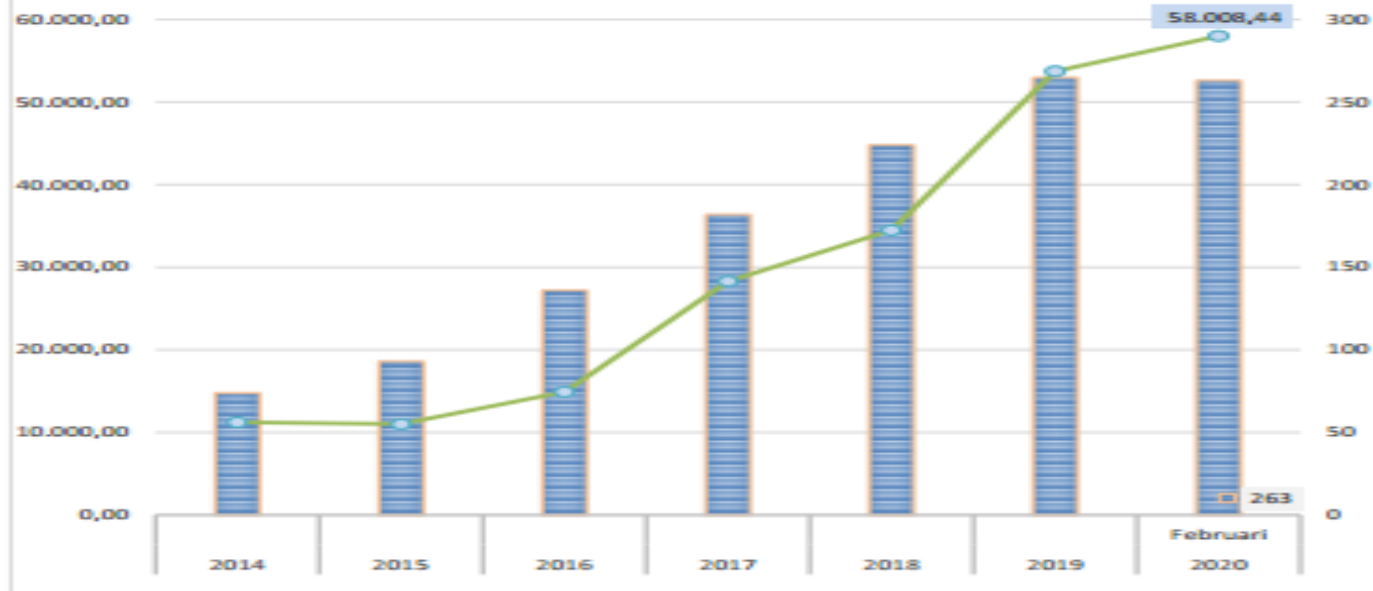

Gambar 2: Tabel perkembangan reksadana syariah (februari 2020)

\section{SIMPULAN}

Investasi kini menjadi salah satu kegiatan perekonomian yang paling banyak diminati oleh orang di beberapa negara maju hingga pada saat ini sudah marak dijumpai di negara berkembang, seperti Indonesia. Investasi sejatinya adalah menempatkan sebagian dana dengan keinginan untuk mendapat keuntungan di waktu yang akan datang. Aktivitas investasi ini terbagi ke dalam beberapa bentuk seperti deposito, saham, sukuk/obligasi, maupun reksadana. Diantara beberapa bentuk investasi itu, reksadana syariah menjadi salah satu tonggak baru dalam perkembangan keuangan syariah di Indonesia.
Reksadana syariah merupakan kegiatan yang menarik bagi masyarakat yang akan menanamkan hartanya di lantai bursa sesuai dengan aturan syariah. Sebagimana reksadana syariah adalah sarana atau wadah yang dipakai untuk menghimpun dana dari masyarakat yang selanjutnya akan diinvestasikan ke portofolio efek yang dibantu pengelolaannya oleh manajer investasi. Dalam hal ini, portofolio efek dapat berupa instrumen pasar uang, saham, obligasi, atau gabungan dari beberapa bentuk di antaranya.

Mekanisme operasional dalam reksadana syariah terdiri dari dua alur yakni pertama, akad antara pemilik modal de- 
ngan manajer investasi dilaksanakan dengan sistem wakalah. Kedua, antara manajer investasi dengan pengguna investasi dilangsungkan dalam akad mudharabah. Prinsip yang mendasar dalam reksadana syariah yakni prinsip mudharabah atau qiradh, yang artinya sebuah kegiatan dimana pemilik modal memberikan seba- gian hartanya pada orang lain yang berkompeten untuk selanjutnya akan dikelola dengan ketentuan bahwa keuntungan yang akan diperoleh dari hasil pengelolaan tersebut dibagi sesuai dengan syarat-syarat yang telah disepakati oleh kedua belah pihak sebelumnya.

\section{Daftar Pustaka}

Achsien, Iggi H. 2000. Investasi Syariah di Pasar Modal: Menggagas Konsep dan Praktek Manajemen Portofolio Syariah. Jakarta: Gramedia Pustaka Utama.

Al Arif, M. Nur Riyanto. 2001. Lembaga Keuangan Syariah: Suatu Kajian Teoritis Praktis. Bandung: Pustaka Setia.

Fatwa DSN Nomor 20/DSN-MUI/IV/2001tentang Reksadana Syariah, Himpunan Fatwa Dewan Syariah Nasional. Jakarta: Intermasa.

Fatwa DSN Nomor 40/DSN-MUI/X/2003 tentang Pasar Modal dan Pedoman Umum Penerapan Syariah di Bidang Pasar Modal, Himpunan Fatwa Dewan Syariah Nasional. Jakarta: Intermasa.

Haerisma, Alvien Septian. 2014. Pengantar Reksadana Syariah (Introduction Of Islamic Mutual Fund), Al-Amwaal Jurnal Kajian Ekonomi dan Perbankan Syariah, Vol 6, No. 2.

Hammad. 2005. Briefcase Book Edukasi Profesional Syariah Investasi Halal di Reksadana Syariah. Jakarta: Renaisan.

Ismanto, Kuat. 2012. Prospektus Reksadana Sebagai Prinsip Kejujuran Bisnis Syariah, Jurnal Hukum Islam Volume 10, Nomor 2, Juni

Jogiyanto. 2007. Teori Portofolio dan Analisis Investasi. Yogyakarta: BPFE Yogyakarta. Manan, Abdul. 2012. Hukum Ekonomi Islam. Jakarta: Kencana.

Pratomo, Eko Priyo dan Nugraha Ubaidillah. 2009. Reksadana: Solusi Perencanaan Investasi di Era Modern . Jakarta: Gramedia Pustaka Utama.

Soemitra, Andri. 2009. Bank dan Lembaga Keuangan Syariah. Jakarta: Kencana.

Undang-Undang Republik Indonesia Nomor 8 Tahun 1995 tentang Pasar Modal Yusuf, Muhammad. 2011. Bisnis Syari'ah. Jakarta: Mitra Wacana Media. 
dery ariswanto 